\title{
A List of Journal Articles Published in 2008 and 2009 on Auxiliary Equipment
}

DOI: $10.1134 / \mathrm{S} 0040601510080185$

M. G. Abuov and P. A. Kovgan, "A Study of HeatTransfer Processes in a Countercurrent Cyclone Heat Exchanger," Teploenergetika, No. 12 (2009) [Therm. Eng., No. 8 (2009)].

Yu. N. Agapov, V. G. Stognei, and M. A. Khaustov, "Selecting and Substantiating the Design of an Air Heater for a Small-Capacity Boiler Unit," Prom. Energ., No. 12 (2009).

V. Yu. Aleksandrov and K. K. Klimovskii, "A Procedure for Calculating Gas Ejectors," Teploenergetika, No. 8 (2009) [Therm. Eng., No. 8 (2009)].

V. Yu. Aleksandrov and K. K. Klimovskii, "Optimization of Multistage Gas Ejectors," Teploenergetika, No. 9 (2009) [Therm. Eng., No. 9 (2009)].

S. N. Anichkov, R. I. Giniyatullin, and A. M. Zykov, "Improving the Efficiency of Entrapping Fly Ash in Wet Ash Entrapping Apparatuses," Elektr. Stn., No. 8 (2009).

K. E. Aronson, Yu. M. Brodov, A. Yu. Ryabchikov, et al., "Experience Gained from Development of Modernized Oil Coolers for the Oil Supply System Used in 800-MW Turbines," Teploenergetika, No. 8 (2009) [Therm. Eng., No. 8 (2009)].

A. A. Avdeev, A. S. Shamarokov, and L. N. Fal'kovskii, "Header-Platen High-Pressure Heaters," Teploenergetika, No. 2 (2009) [Therm. Eng., No. 2 (2009)].

A. A. Bakulina and I. T. Ter-Mateosyants, "Pipeline Valves: the Direction of Motion," Akademiya Eneregetiki, No. 4 (2009).

B. I. Basok, T. G. Belyaeva, A. A. Rutenko, and A. A. Lunina, "An Analysis of Economic Efficiency in Constructing Heat Pump Systems for Heat Supply Purposes,” Prom. Teplotekhn., No. 4 (2008).

Yu. V. Belousov, S. F. Zhdanov, and S. E. Nikol'skii, "Modern Apparatuses Produced by OOO Gazkholodtekhnika for Air Cooling of Oil," Gazoturb. Tekhnol., No. 6 (2008).

A. V. Bilan and V. N. Bilan, "Making the Tube System of Horizontal Delivery Water Heaters More Reliable," Teploenergetika, No. 9 (2009) [Therm. Eng., No. 9 (2009)].

V. V. Burenin, "Purification and Neutralization of Dust-Gas-Air Emissions from Thermal Power Industry Enterprises,” Prom. Energ., No. 8 (2009).

A. A. Chichirov, N. D. Chichirova, I. Yu. Silov, et al., "Mathematical Simulation of Material Flows in the
Circulation Cooling System of a Thermal Power Station," Izv. Vyssh. Uchebn. Zaved., Probl. Energetiki, Nos. 5-6 (2008).

T. V. Derevyanko, V. M. Petukhov, I. M. Egorov, and A. N. Ignashin, "Specific Features Relating to Operation of the Ultrafiltration Plant at OAO Mosenergo's TETs-9 Cogeneration Station," Energetik, No. 2 (2009).

A. V. Dmitriev, G. Kh. Gumerova, and N. A. Nikolaev, "Separating Carbon Dioxide from Gaseous Emissions Produced at Thermal Power Stations in Vortex Apparatuses Equipped with Rotating Porous Atomizers," Izv. Vyssh. Uchebn. Zaved., Probl. Energetiki, Nos. 1-2 (2009).

V. K. Elsukov, "The Influence of Electrostatic Phenomena on the Efficiency of TsBR-150U Battery Cyclones," Prom. Energ., No. 2 (2009).

V. L. Fedyaev, A. B. Mozo, I. V. Morenko, et al., "The Operational Efficiency of Industrial Cooling Towers," Izv. Vyssh. Uchebn. Zaved., Probl. Energetiki, Nos. 1-2 (2009).

V. L. Fedyaev, B. A. Snigirev, I. V. Morenko, et al., "Modernization of SK-1200 Cooling Towers," Izv. Vyssh. Uchebn. Zaved., Probl. Energetiki, Nos. 5-6 (2009).

N. M. Fialko, Yu. V. Sherenkovskii, A. I. Stepanova, et al., "Optimizing the Design Parameters of a Boiler Unit's Condensing Heat-Recovery Device," Prom. Energ., No. 3 (2008).

M. Goff, S. L. Demenok, and S. M. Sivukha, "A Technology for Enhancement of Shell-and-Tube Heat Exchangers," Novosti Teplosnab., No. 9 (2009).

Yu. M. Gofman, "Factors Causing Damage to the Startup Separators of Boilers," Energetik, No. 2 (2009).

V. I. Gombolevskii, B. P. Afanas'ev, Yu. A. Radin, et al., "Putting Centrifugal-Jet Atomizers in Use in the Deaeration Devices of the PGU-39 CombinedCycle Plant at the Sochi Thermal Power Station," Elektr. Stn., No. 5 (2009).

G. Kh. Gumerova, A. V. Dmitriev, and N. A. Nikolaev, "Purification of Low-Head Gaseous Emissions from Power-Generating Units in Vortex Apparatuses Equipped with Rotating Porous Atomizers," Prom. Energ., No. 6 (2009). 
V. A. Khaimov, E. I. Puzyrev, V. N. Kokin, et al., "Separators for Removing Solid Particles from the Hot Reheat Steam Lines of Large Power Units," Elektr. Stn., No. 9 (2009).

Yu. M. Khlebalin, "Application of Jet Compressors for Increasing the Power Output of Industrial-Heating Cogeneration Stations,” Prom. Energ., No. 1 (2009).

A. I. Khudyakov and V. A. Khudyakov, "Development of a Plate-Type Heat Exchanger for a LargeCapacity Power Installation," Tyazh. Mashinostr., No. 11 (2009).

R. N. Konovalov and A. V. Agafonov, "The Specific Features of Air Cleaning Systems Used in SmallCapacity Gas Turbine Units Revealed from Test Results and Field Experience," Gazoturb. Tekhnol., No. 5 (2008).

V. K. Konovalov, O. V. Yashkin, and V. V. Ermakov, "Optimizing the Parameters of a System for Pulsed Pneumatic Transportation of Ash from Electric Precipitators at Thermal Power Stations and Putting This System in Operation," Teploenergetika, No. 5 (2009) [Therm. Eng., No. 5 (2009)].

S. D. Korneev, L. A. Maryushin, S. Ya. Efendiev, and E. A. Shakirova, "Prospects for Improvement of Evaporating Plants at Thermal Power Stations," Energetik, No. 7 (2009).

A. V. Korolev, "Analyzing the Work of a Pressure Shock in Steam-Water Injectors," Izv. Vyssh. Uchebn. Zaved., Energetika, No. 2 (2009).

A. V. Koryagin and R. V. Solov'ev, "An Expansion Engine-Generator Unit with Two Intermediate Heating Circuits,” Izv. Vyssh. Uchebn. Zaved., Probl. Energetiki, Nos. 1-2 (2009).

A. V. Koryagin and R. V. Solov'ev, "Installation of Expansion Engine-Generator Units at the Cogeneration Stations of Industrial Enterprises," Energosber., Vodopodg. No. 5 (2009).

V. R. Kovalyukh, "A Universal Automated Vibration System for Uninterrupted Supply of Wet Coal from a Hopper with Any Friability Characteristics," Elektr. Stn., No. 9 (2009).

S. G. Kozlov, A. P. Skuratov, A. I. Suroyakov, and A. A. Belogorskii, "A Supplementary System for Removing Entrainment for Boilers Equipped with Stoker Furnaces," Energetik, No. 6 (2009).

A. V. Krylov, "Modernization of the TurbineDriven Feedwater Pumps Used in the 1260-MW Power Unit at the Kostroma District Power Station," Energosber., Vodopodg. No. 3 (2009).

A. O. Kurchev, N. N. Elin, V. E. Mizonov, and V. I. Subbotin, "Mathematical Simulation of the Thermal Process in a Regenerator with Phase-Transition Packing," Prom. Energ., No. 12 (2008).

A. S. Latkin, B. E. Parshin, O. L. Basmanov, and V. V. Korshunov, "Development of Separators for Separating Geothermal Steam-Water Heat Carriers,"
Teploenergetika, No. 8 (2009) [Therm. Eng., No. 8 (2009)].

S. R. Levandovskii and E. V. Afanasenko, "An Analysis of the Thermal Parameters Characterizing the Operation of Self-Bearing Metal Smoke Stacks of Small and Medium Capacity," Novosti Teplosnab., No. 8 (2009).

A. V. Levin and N. N. Laptev, "A System for Electrically Starting a Gas Turbine Unit in Operation," Gazoturb. Tekhnol., No. 3 (2009).

M. Yu. Lifshits, Yu. V. Solodyannikova, and V. V. Solodyannikov, "System Principles of Selecting a Technology for Water Treatment Plants at Thermal Power Stations," Energosber., Vodopodg., No. 5 (2009).

O. V. Mal'khanov, "Energy-Efficient TurbineExpansion Units Intended for Producing Electric Energy at the Gas Control Points of Thermal Power Stations," Energosber., Vodopodg., No. 1 (2009).

E. M. Marchenko and O. V. Mal'khanov, "Turbine-Expansion Units for Efficient Use of Energy due to Pressure Difference of Natural Gas," Energosber., Vodopodg., No. 4 (2009).

V. E. Mikhailov, "Measures to Prevent Icing of Elements of the Air Intake Path Used in the Gas Turbine Units of Power-Generating Combined-Cycle Plants," Izv. Vyssh. Uchebn. Zaved., Probl. Energetiki, Nos. 9-10 (2009).

V. E. Mikhailov, "The Design Features of the Air Intake Path Used in the GTE-65 Gas Turbine Unit Installed at OAO Mosenergo's TETs-9 Cogeneration Station," Prom. Energ., No. 12 (2009).

F. N. Myagkov, M. L. Kostyrev, A. I. Dubaev, and N. V. Motovilov, "Simulation of Pumps with Adjustable Rotation Frequency," Elektr. Stn., No. 6 (2009).

Yu. A. Pechenegov, R. V. Bogatenko, A. V. Kosov, et al., "Parameters Characterizing Throttle-Type Condensate Removers," Prom. Energ., No. 7 (2009).

A. I. Petruchek, "Thermal Calculation of SprayEjection Cooling Towers," Energosber., Vodopodg. No. 2 (2009).

V. B. Prokhorov, V. K. Konovalov, and V. V. Ermakov, "Studying the Mechanism Governing the Outflow of Ash from a Hopper under Gravity to Optimize the Design of the Assembly Used to Remove Ash from the Electric Precipitator's Hopper into the Transportation Pipeline in the Ash Pneumatic Transportation System," Energosber., Vodopodg. No. 4 (2009).

A. Yu. Ryabchikov, Yu. M. Brodov, K. E. Aronson, et al., "Experience Gained from Modernization of Shell-and-Tube Water-to-Water Heat Exchangers," Energetich. Mashiny, Ustan., Nos. 1-2 (2008).

I. A. Sakov, "Application of Variable-Frequency Electric Drives for Controlling the Drain Pumps of Low-Pressure Heaters Used in Turbine Units at Cogeneration Stations," Teploenergetika, No. 10 (2009) [Therm. Eng., No. 10 (2009)]. 
A. A. Salamov, "Air Coolers with Wetted Surface," Energetik, No. 12 (2009).

V. P. Semenov and N. I. Platonov, "A Comprehensive Analysis of a Contact Heat Exchanger with Recirculation of Fluid for Recovering the Heat of Flue Gases," Prom. Energ., No. 11 (2009).

V. P. Semenov, N. I. Platonov, and Yu. M. Goldobin, "Thermal Engineering Indicators of a Film Contact Heat Exchanger with Recirculation of Heated Liquid," Energosber., Vodopodg., No. 5 (2009).

G. D. Shekun, "Approximating the Head Characteristics and Characteristic Surfaces of Dynamic Pumps by Means of an Exponential Function," Teploenergetika, No. 8 (2009) [Therm. Eng., No. 8 (2009)].

N. S. Shestakov, A. E. Leikam, D. F. Serant, and E. E. Russkikh, "Modern Tendencies in the Development of Coal Gasification Systems," Prom. Energ., No. 2 (2009).

V. G. Shilov, A. V. Knyazev, A. I. Elkin, and P. I. Bazhan, "The Operation of High-Reliable Intensified Shell-and-Tube Heat Exchangers," Novosti Teplosnab., No. 7 (2009).

Yu. V. Solov, V. A. Semashko, V. V. Varnashov, et al., "Making the External Gas Conduits and Smoke Stacks at Thermal Power Stations More Reliable and Environmentally Safer," Energosber., Vodopodg., No. 2 (2009).

R. V. Solov'ev, "Comparing the Operational Efficiencies of Expansion Engine-Generator Units with Different Methods for Heating Gas," Energosber., Vodopodg., No. 6 (2009).

E. V. Somova, V. I. Kisina, A. L. Shvarts, et al., "Studies of a Direct-Contact Feedwater Heater in a Fragment of the Secondary Coolant Circuit of a New-
Generation Reactor Plant,” Teploenergetika, No. 6 (2009) [Therm. Eng., No. 6 (2009)].

I. I. Strikha, "Operational Reliability of Smoke Stacks," Novosti Teplosnab., No. 3 (2009).

V. B. Tupov and D. V. Chugunkov, "Noise Silencers on Discharges of Steam from Power-Generating Boilers," Teploenergetika, No. 8 (2009) [Therm. Eng., No. 8 (2009)].

B. P. Vasil'ev and V. D. Belousov, "Sophisticated Heat-Transfer Equipment for Enterprises of the Fueland-Energy Complex," Tyazh. Mashinostr., No. 2 (2009).

V. I. Velikovich, Yu. M. Brodov, and M. A. Nirenshtein, "Delivery-Water Heaters Used in the Cogeneration Units Produced by the Ural Turbine Works," Teploenergetika, No. 9 (2009) [Therm. Eng., No. 9 (2009)].

I. I. Vershinin, "A Pneumatic-Rotor Method for Cleaning Pipes and Heat-Transfer Tubes," Energetik, No. 11 (2009).

Yu. V. Vikhrev, "The Development of New Systems for Binding Carbon Dioxide at Power Stations," Energetik, No. 5 (2009).

L. M. Zhivilova, Yu. A. Slobodskaya, D. S. Smetanin, and I. A. Orlova, "Modern Lines of the Development of Process Circuits, Equipment, and Systems for Monitoring and Control of Water Treatment at Power Stations," Energetik, No. 12 (2008).

M. G. Ziganshin and A. V. Dmitriev, "Calculating the Efficiency of Separating Emulsion Flows in Vortex-Type Apparatuses," Prom. Energ., No. 3 (2009).

V. I. Zvegintsev and I. I. Shabanov, "Experience Gained with Construction of Pneumatic-Pulse Systems for Cleaning the Convection Heating Surfaces of Boiler Units," Energetik, No. 1 (2009). 